Dept. of Food Hygiene,

Animal Health Research Institute, Dokki, Giza

\title{
PREVALENCE OF SOME PATHOGENS IN SOME MEAT PRODUCTS AND THEIR CONTACT SURFACES IN A MEAT PRODUCT FACTORY
}

(With 3 Tables)

By

\author{
K.M. EL-KHAWAS and AMANI L.F. AHMED \\ (Received at 11/3/2008)
}

مدى تواجد بعض الميكروبات الضارة فى بعض منتجات اللحوم والاسطح

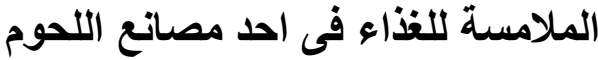

خالد محد سبي الخواص ، أمانس لطفى فرج أحمد

من خلال هذه الدر اسة التى استمرت لمدة ثلاثة شهور و على مدى ثلاث زيار ات لاحد المد مصانع

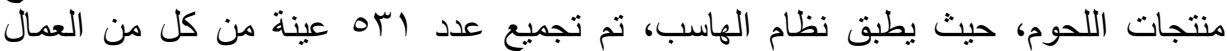
و الأسطح الملامسة للغذاء والأغذية قبل وأثناء العمل من ثلاث الثاث مناطق هى منطقة التجهيز

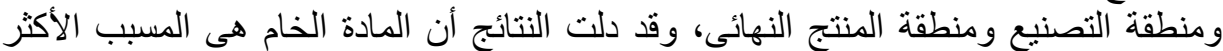

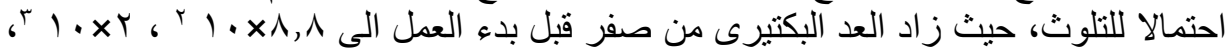

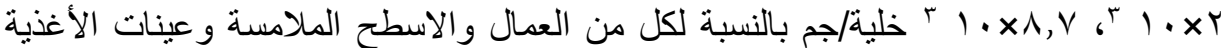

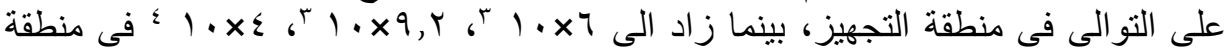

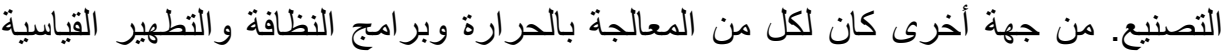

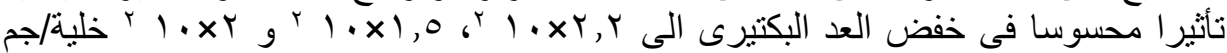

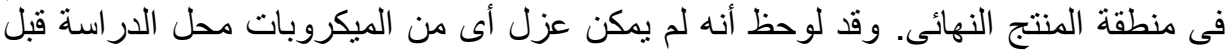

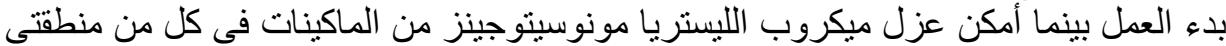

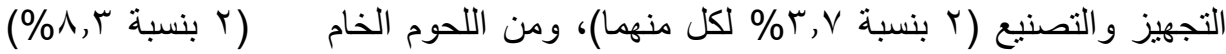

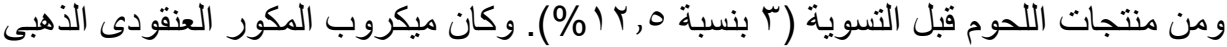

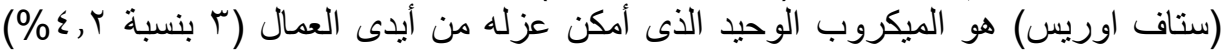

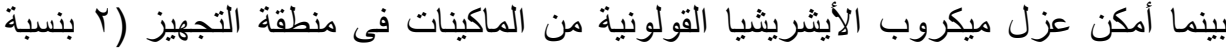

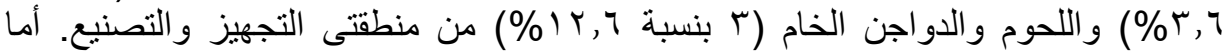

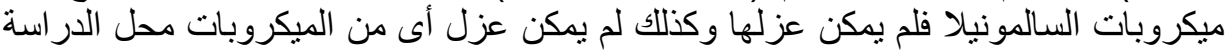

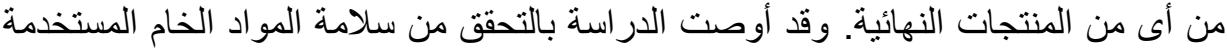

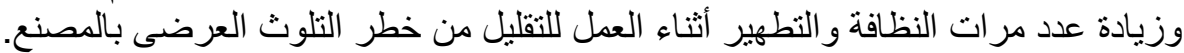

\section{SUMMARY}

Over a period of three months, throughout three visits to a meat product plant where HACCP system is in place, a total number of 531 workers, surface swabs and food samples were collected pre- and during work 
from three areas (preparing, processing and packaging). Raw materials were the most probable cause of contamination. The aerobic plate counts increased from zero before working to $8.8 \times 10^{2}, 2.0 \times 10^{3}$ and $8.7 \times 10^{3}$ $\mathrm{cfu} / \mathrm{g}$ or $\mathrm{cm}^{2}$ in workers, meat contact surfaces and food samples, respectively in preparing area and to $6 \times 10^{3}, 9.2 \times 10^{3}$ and $4 \times 10^{4} \mathrm{cfu} / \mathrm{g}$, in production area. Meanwhile the proper heat treatment and sanitary standard operating procedures significantly decreased the count to $2.2 \times 10^{2}, 1.5 \times 10^{2}$ and $2 \times 10^{2} \mathrm{cfu} / \mathrm{g}$ in the packing area. None of the tested microorganisms was isolated prior to food preparation. However, after preparation and processing L. monocytogenes was isolated from machines of preparation area $(2,3.7 \%)$, machines of production area $(2,3.7 \%)$, raw meat $(2,8.3 \%)$ and processed meat $(3,12.5 \%)$. S. aureus was the only isolated pathogen from workers hands $(3,4.2 \%)$. E. coli could be isolated from machines of preparation area $(2,3.6 \%)$ and raw meat and chicken $(3,12.6 \%)$ in preparation and processing areas, but Salmonella couldn't be isolated. None of the tested microorganisms could be isolated from any of the final products. For such plant, it's recommended to verify the quality of purchased raw material and to decrease the intervals of sanitization program to decrease the risk of cross contamination.

Key words: Meat products, meat contact surfaces, L. monocytogenes, S. aureus, Salmonella

\section{INTRODUCTION}

Ready to eat (RTE) foods including red meats, poultry and seafood have been documented to serve as vehicles for several bacterial pathogens and foodborne outbreaks have been associated with the consumption of contaminated RTE foods (Guerra et al., 2001; Borch and Arinder, 2002; Gudbjornsdotttir et al., 2004).

HACCP is becoming established and has been successful in the food industry, such as its association with reduction in pork carcass contamination (Bolton, et al., 1999) and improving the control of food production in catering establishments (Martinez-Tome et al., 2000).

Significantly more unsatisfactory samples were obtained from premises where no HACCP system was in place, as compared with those which had an undocumented or documented hazard analysis system in place (Gillespie et al., 2000).

Commercially food production, catering and industrial food preparation must adhere to legislation regarding food safety. Analysis of 
the hazards were recognized through the world by WHO, FDA, FAO, European commission, and is becoming increasingly applied in developing countries (Gorman et al., 2002).

L. monocytogenes can cause listeriosis in pregnant women, immuncompromized and eldery (Slutsker and Schuchat, 1999). Listeriosis has a mortality rate of 20-30\% and thus represents a serious public health concern (Schuchat et al., 1991). When present in the environment, L. monocytogenes can contaminate finished products through employee contact surfaces (such as hand tools, gloves and aprons), food contact surfaces and non food contact surfaces (Tompkin et al., 1999). The prevalence of Listeira spp. in RTE meats have been variable ranging from $1.8 \%$ to $48 \%$ (Gibbons et al., 2006). There are several reports of listeriosis associated with the consumption of RTE meats (Faber and Peterkin, 1991; Anon, 2001). Some of these epidemics resulted in mortalities, as well as large scale recalls of implicated RTE foods (Rouquete and Berche, 1996; Norrung, 2000; USDA, 2002).

Other enteric pathogens have been isolated form RTE foods including E. coli and Salmonella emphasizing the risk posed by consumption of these foods (Tsuji et al., 2002; Faustini et al., 2003; Lee and Middleton, 2003; Haeghebaet et al., 2003). Pathogens such as Listeria spp., Salmonella spp. and E. coli have all been recovered from raw meats (Adesiyun, 1993). In many countries $S$. aureus is the second or third common cause of foodborne disease outbreaks behind Salmonella (Rosec et al., 1997). S. aureus was the predominant microorganism found on hands of food preparators (Ryan et al., 1996). Scott and Bloomfield (1990) identified the ability of S. aureus to cause cross-contamination for up to $24 \mathrm{~h}$ via the fingertips.

This study was conducted to evaluate the aerobic plate count as well as prevalence of Listeria spp. Salmonella spp., E. coli and S. aureus in raw processed and finished meat and chicken products together with the different premises, meat contact surfaces and employee at different processing stages and areas in a plant where HACCP system is implemented.

\section{MATERIALS and METHODS}

\section{Sampling procedure:}

Over a period of 3 months through three visits to a meat product plant where HACCP system is in place, 225; 72 workers and 153 surfaces swabs from workers and contact surfaces were collected prework directly after cleaning and disinfection. Another 306 samples of 72 
workers, 153 food contact surface swabs and 81 food samples were collected during at least midway through a shift and towards the end of the working day from various processing stages. All swabbed surfaces were in direct contact with food. The plant was divided into three main areas representing raw material preparing area, processing area and packaging area. Each area was sampled for workers (gloves and aprons), surfaces [machines (breaker, grinder, mixer, cutter, filler and slicer), utensils (tables, knives, containers and cutting boards)] and food (raw meat, poultry and their products). Swabs from workers' hands and 25 $\mathrm{cm}^{2}$ from food contact surfaces using sterile swab moisten with neutralizing buffer and 25 grams of food were collected. All samples were kept in an icebox and transported without delay to the laboratory.

\section{Bacteriological analysis:}

- Preparation of samples

On arrival to the laboratory, samples were homogenized with buffer peptone (1:10). Ten-fold serial dilutions were prepared using buffer peptone for the following analysis:

1. Aerobic plate count: using pour plate technique onto plate count agar and incubating at $35^{\circ} \mathrm{C}$ for $48 \mathrm{~h}$ according to APHA (1992).

2. Isolation of Salmonella: samples were pre-enriched on buffer peptone for $24 \mathrm{~h}$ at $37{ }^{\circ} \mathrm{C}$, enriched on Rappaport Vassiliadis for $24 \mathrm{~h}$ at $41.5{ }^{\circ} \mathrm{C}$ and tetrathionate broth at $37^{\circ} \mathrm{C}$ for $24 \mathrm{~h}$ then plated on XLD and Brilliant green agar at $37^{\circ} \mathrm{C}$ for $24 \mathrm{~h}$, according to APHA (1992).

3. Isolation of E. coli: using lauryl sulphate broth incubated at $35^{\circ} \mathrm{C}$ for 24-48 h followed inoculation of loopful from positive tubes on $E$. coli broth incubated at $45.5^{\circ} \mathrm{C}$ for $24-48 \mathrm{~h}$ then plated on eosin methylene blue agar and incubated at $35^{\circ} \mathrm{C}$ for $24-48 \mathrm{~h}$ according to APHA (1992).

4. Isolation of $S$. aureus: using selective enrichment procedure, by enrichment on brain heart infusion broth at $37{ }^{\circ} \mathrm{C}$ for $24 \mathrm{~h}$, then streaking on Barid Parker agar at $35^{\circ} \mathrm{C}$ for $48 \mathrm{~h}$ according to APHA (1992).

5. Isolation of L. monocytogenes : using Listeria enrichment broth at $30^{\circ} \mathrm{C}$ for $48 \mathrm{~h}$ and plating on Oxford agar at $35^{\circ} \mathrm{C}$ for $24-48 \mathrm{~h}$ according to FAO (1992)

The results were statistically analysed using SPSS for Windows version 10. "SPSS Inc. Headquarters, Chicago, Illinois USA."

\section{RESULTS}


Table 1: Mean APCs and incidence of isolated microorganisms in different areas for workers samples

\begin{tabular}{|c|c|c|c|c|c|c|c|c|c|c|}
\hline \multirow{2}{*}{ Area } & \multirow[t]{2}{*}{ Samples } & \multicolumn{2}{|c|}{ No. } & \multicolumn{2}{|r|}{ APC } & \multicolumn{5}{|c|}{ Isolates No. (\%) } \\
\hline & & B & D & B & D & B & E. coli & L. monocytogenes & S. aureus & Salmonella \\
\hline \multirow{3}{*}{$\begin{array}{l}\text { Preparing } \\
\text { area }\end{array}$} & Workers & 24 & 24 & -ve & $8.8 \times 10^{2} \mathbf{A}$ & -ve & -ve & -ve & \multirow{3}{*}{$1(4.2 \%)$} & \multirow[t]{3}{*}{-ve } \\
\hline & Gloves & & & & $7.7 \times 10^{2}$ & & & & & \\
\hline & Aprons & & & & $1.0 \times 10^{3}$ & & & & & \\
\hline \multirow{3}{*}{$\begin{array}{l}\text { Production } \\
\text { area }\end{array}$} & Workers & 24 & 24 & -ve & $6.0 \times 10^{3} \mathrm{~A}$ & -ve & & & \multirow{3}{*}{$1(4.2 \%)$} & \multirow[t]{3}{*}{$-\mathrm{ve}$} \\
\hline & Gloves & & & & $5.0 \times 10^{3}$ & & & & & \\
\hline & Aprons & & & & $7.0 \times 10^{3}$ & & & & & \\
\hline \multirow{3}{*}{$\begin{array}{l}\text { Packing } \\
\text { area }\end{array}$} & Workers & 24 & 24 & -ve & $2.2 \times 10^{2} \mathbf{a}$ & $-\mathrm{ve}$ & $-\mathrm{ve}$ & $-\mathrm{ve}$ & \multirow[b]{3}{*}{$1(4.2 \%)$} & \multirow[t]{3}{*}{$-\mathrm{ve}$} \\
\hline & Gloves & & & & $1.4 \times 10^{2}$ & & & & & \\
\hline & Aprons & & & & $3.0 \times 10^{2}$ & & & & & \\
\hline
\end{tabular}

B: before work $\quad$ D: during work There is significance difference between means containing the same capital and small letter

Table 2: Mean APCs and incidence of isolated microorganisms in different areas for surfaces samples

\begin{tabular}{|c|c|c|c|c|c|c|c|c|c|c|}
\hline \multirow[t]{2}{*}{ Area } & \multirow[t]{2}{*}{ Samples } & \multicolumn{2}{|c|}{ No. } & \multicolumn{2}{|r|}{ APC } & \multicolumn{5}{|c|}{ Isolates No. (\%) } \\
\hline & & B & D & B & D & B & E. coli & L. monocytogenes & S. aureus & Salmonella \\
\hline $\begin{array}{c}\text { Preparing } \\
\text { area }\end{array}$ & \begin{tabular}{|l} 
Surface \\
Machines \\
Breaker \\
Grinder \\
Utensils \\
Tables \\
Knives \\
Containers \\
Cutting boards
\end{tabular} & 54 & 54 & $-\mathrm{ve}$ & \begin{tabular}{|c|}
$2.0 \times 10^{3} \mathbf{A}$ \\
$2.0 \times 10^{3}$ \\
$3.0 \times 10^{3}$ \\
$2.0 \times 10^{3}$ \\
$3.0 \times 10^{3}$ \\
$2.6 \times 10^{2}$ \\
$3.2 \times 10^{2}$ \\
$4.0 \times 10^{3}$ \\
$1.5 \times 10^{3}$
\end{tabular} & $-\mathrm{ve}$ & $\begin{array}{l}1(1.8 \%) \\
1(1.8 \%)\end{array}$ & $\begin{array}{c}1(1.8 \%) \\
1(1.8 \%) \\
- \\
- \\
- \\
- \\
-\end{array}$ & $-\mathrm{ve}$ & $-\mathrm{eve}$ \\
\hline $\begin{array}{l}\text { Production } \\
\text { area }\end{array}$ & \begin{tabular}{|c} 
Surface \\
Machines \\
Mixer \\
Cutter \\
Filler \\
Utensils \\
Tables \\
Knives \\
\end{tabular} & 54 & 54 & $-\mathrm{ve}$ & \begin{tabular}{|c}
$9.2 \times 10^{3} \mathbf{A}$ \\
$1.3 \times 10^{4}$ \\
$8.5 \times 10^{3}$ \\
$1.9 \times 10^{4}$ \\
$1.0 \times 10^{4}$ \\
$4.8 \times 10^{3}$ \\
$4.0 \times 10^{3}$ \\
$5.5 \times 10^{3}$
\end{tabular} & $-\mathrm{ve}$ & -ve & $\begin{array}{c}- \\
2(3.7 \%) \\
- \\
- \\
- \\
-\end{array}$ & $-\mathrm{ve}$ & -ve \\
\hline $\begin{array}{l}\text { Packing } \\
\text { area }\end{array}$ & $\begin{array}{c}\text { Surface } \\
\text { Machines } \\
\text { slicer } \\
\text { Tables } \\
\text { Trolleys } \\
\text { Filler } \\
\text { Utensils }\end{array}$ & 45 & 45 & $-\mathrm{ve}$ & \begin{tabular}{|c|}
$1.5 \times 10^{2} \mathbf{a}$ \\
$1.4 \times 10^{2}$ \\
$2.2 \times 10^{2}$ \\
$1.9 \times 10^{2}$ \\
$5.0 \times 10$ \\
$1.0 \times 10^{2}$ \\
$2.0 \times 10^{2}$
\end{tabular} & $-\mathrm{ve}$ & $-\mathrm{ve}$ & -ve & -ve & -ve \\
\hline
\end{tabular}

There is significance difference between means containing the same capital and small letter

Table 3: Mean APCs and incidence of isolated microorganisms in different areas for food samples. 


\begin{tabular}{|c|c|c|c|c|c|c|c|c|c|c|}
\hline \multirow[t]{2}{*}{ Area } & \multirow[t]{2}{*}{ Samples } & \multicolumn{2}{|c|}{ No. } & \multicolumn{2}{|r|}{ APC } & \multicolumn{5}{|c|}{ Isolates No. (\%) } \\
\hline & & B & $\mathrm{D}$ & $\mathrm{B}$ & $\mathrm{D}$ & B & E. coli & L. monocytogenes & S. aureus & Salmonella \\
\hline $\begin{array}{l}\text { Preparing } \\
\text { area }\end{array}$ & $\begin{array}{c}\text { Food } \\
\text { Meat } \\
\text { Poultry }\end{array}$ & - & 24 & $-\mathrm{ve}$ & $\begin{array}{r}8.7 \mathrm{X} 10^{3} \mathbf{A} \\
5.4 \times 10^{3} \\
1.2 \times 10^{4}\end{array}$ & $-\mathrm{ve}$ & $1(4.2 \%)$ & $\begin{array}{c}2(8.3 \%) \\
-\end{array}$ & $2(8.3 \%)$ & $-\mathrm{ve}$ \\
\hline $\begin{array}{l}\text { Production } \\
\text { area }\end{array}$ & $\begin{array}{c}\text { Food } \\
\text { Meat } \\
\text { Poultry }\end{array}$ & - & 24 & -ve & $\begin{array}{r}4.0 \times 10^{4} \mathbf{A} \\
2.0 \times 10^{4} \\
6.0 \times 10^{4}\end{array}$ & -ve & $\begin{array}{l}1(4.2 \%) \\
1(4.2 \%)\end{array}$ & $\begin{array}{c}3(12.5 \%) \\
-\end{array}$ & $1(4.2 \%)$ & -ve \\
\hline $\begin{array}{l}\text { Packing } \\
\text { area }\end{array}$ & \begin{tabular}{|l|} 
Food \\
Meat products \\
Poultry \\
products \\
\end{tabular} & - & 33 & $-\mathrm{ve}$ & $\begin{array}{r}2.0 \times 10^{2} \mathbf{a} \\
1.5 \times 10^{2} \\
2.5 \times 10^{2} \\
\end{array}$ & -ve & -ve & -ve & $-\mathrm{ve}$ & -ve \\
\hline
\end{tabular}

There is significance difference between means containing the same capital and small letter

\section{DISCUSSION}

It was evident in this study that following a thorough cleaning and disinfection of the plant (pre-working) all food contact surfaces and workers swabs for the 3 sampled areas were proved to be uncontaminated with the aerobic bacteria (Table 1, 2 and 3), an indication that the cleaning and disinfection exercise instituted by the plant successfully eliminated potential contaminants on the workers and food contact surfaces.

Results from the APCs (Table 1) illustrate a significant increase in the bacterial load for workers swabs sampled prior to food handling, nil / hand compared to each of those sampled during preparation $\left(8.8 \times 10^{2} \mathrm{cfu} / \mathrm{hand}\right)$ and processing $\left(6 \times 10^{3} \mathrm{cfu} / \mathrm{hand}\right)$. That was also true when applied to the equipment swabs (including machines and utensils) as they were free from the APC prior to preparation of the raw food materials while showed $2 \times 10^{3} \mathrm{cfu} / \mathrm{cm}^{2}$ and $9.2 \times 10^{3}$ after preparation and processing of the raw food, respectively (Table 2 ).

These results were unsurprised considering that HACCP system is established at the plant; food hygiene training of the staff, physical separation of raw food materials and unwrapped cooked RTE foods by means of separate refrigerators, equipment, utensils, serving counters, handling areas and surfaces), the use of separate staff, adequate temperature control of heat treatments and of freezers and refrigerators. In this concern, Gillespie et al, (2000) stated that significantly unsatisfactory or unacceptable samples were obtained from premises where no HACCP system was in place as compared with these which had an undocumented or documented hazard analysis system.

Results highlighted that raw materials were the most probable contributory factor of causing contamination of both the workers (hands and aprons) and the machines and utensils. That was proven by 
observing the bacterial count (Table, 3) of the raw meat and chicken $\left(8.7 \times 10^{3} \mathrm{cfu} / \mathrm{g}\right)$. This proportionally high bacterial load could contaminate both workers and the used machines and utensils of the preparing area. The condition that emphasize the spread of bacteria in the working environment when preparing meat and chicken. This result agrees with Gorman et al. (2002) who observed that chicken samples as raw material showed contamination values in the upper ranges test $\left(>10^{5} \mathrm{cfu} / \mathrm{g}\right.$ ) in $84 \%$ of the samples. The case which is contributed to an increase in the contamination level of worker's hands from $60 \%$ to $88 \%$ at the frequency range $10^{3}-<10^{5} \mathrm{cfu} / \mathrm{g}$. That is also the case in the counter tops and draining boards before and after chicken preparation. The raw food materials in addition to their additives (spices, salt,...) spread the contaminations to the workers' hands and the machines (mixer, cutter, filler) of the production area. That is the cause of increasing the mean bacterial counts to $6 \times 10^{3}$ and $9.2 \times 10^{3} \mathrm{cfu} / \mathrm{g}$, respectively resulting in prepared food with mean counts of $4 \times 10^{4} \mathrm{cfu} / \mathrm{g}$.

The effect of the proper temperature / time and the good manufacturing practice (GMP) in the plant was shown through the significant $(\mathrm{P}<0.05)$ bacterial decrease of the finished products $\left(2 \times 10^{2}\right.$ cfu/g) (Table 3).

Results also highlighted the significant $(\mathrm{P}<0.05)$ increase of the contamination rate of workers handling the raw food materials in both of the preparing area $\left(8.8 \times 10^{2} \mathrm{cfu} / \mathrm{g}\right)$ and the production area $\left(6 \times 10^{3} \mathrm{cfu} / \mathrm{g}\right)$ than those handling the final products $\left(2 \times 10^{2}\right)$ (Table 1). The same observation was achieved throughout comparing the contamination rate of equipment utilizing the raw materials of both preparing are $\left(2 \times 10^{3}\right)$ and processing one $\left(9.2 \times 10^{3} \mathrm{cfu} / \mathrm{cm}^{2}\right)$ compared to those utilizing the cooked finished products $\left(1.5 \times 10^{2} \mathrm{cfu} / \mathrm{cm}^{2}\right)(\mathrm{P}<0.05)$ (Table 2).

Prior to food preparation, all workers' hands, machines and utensils were free of all the tested microorganisms. However, after preparation and processing L. monocytogenes was the most isolated microorganisms in both preparation area [(meat breaker and grinder, 2 $(3.7 \%)$ ] and the production area [mixer $2(3.7 \%)$ ] (Table 2). The pathogen could also be isolated from $2(8.3 \%)$ of raw meat samples and $3(12.5 \%)$ of processed meat products (Table 3$)$.

The ability of foodborne microorganisms as Salmonella and Listeria spp. to become disseminated from naturally contaminated foods (such as chicken) to various hands and food contact surfaces is well known (Gorman et al., 2002). 
Throughout the present study we observed that in spite of the studied plant applied restrict sanitary programs according to HACCP system L. monocytogenes could be isolated from various machines and utensils. The same findings were achieved by several studies which have shown that L. monocytogenes is capable of contaminating food processing machines with bacterial attachment and biofilm formation representing a source of potential contamination of food products (Autio et al. 1999). Once attached to a surface, L. monocytogenes appear to be more difficult to be removed (Autio et al., 1999, Aase et al., 2000 and Beresford et al., 2001). A study led by Lunden et al., 2002) showed that such equipment with poor hygienic properties design is susceptible to persistent L. monocytogenes contamination. It was observed that remnants on the machines grooves and surfaces were associated with $L$. monocytogenes detection. This conclusion was confirmed by a study led by Chasseignaux et al. (2001) (7.4\%) raw pork meat plant.

In the present study, the incidence of L. monocytogenes contaminated the surfaces of the premises was $2.6 \%$ which is more or less in agreement with the incidence of the pathogen in meat processing plants in Nordic countries (0-15.1\%) (Gudbjornsdottir et al., 2004). While it was lower than the contamination levels of the equipment of a meat plant (37\%) recorded by Chasseignaux et al. (2002) and extremely lower than that observed by Thevento et al. (2005) (50.9\%).

The incidence of $L$. monocytogenes in raw and processed meat (prior to heat treatment) was $5(20.8 \%)$. The pathogen couldn't be isolated from any of the final products (post heat treatment). In this concern the incidence of L. monocytogenes in raw meats is largely variable, from a low incidence as in our findings to high incidence which may reach to $38.9-80 \%$ as recorded by Gibbons et al. (2006).

It was observed through this study that $S$. aureus was the only isolated pathogen from two workers hands $(4.2 \%)$ after preparation and processing the raw food materials. In this concern, Gorman et al. (2002) achieved the same result. They found that $S$. aureus was the predominant microorganism found on hands of food preparators following food preparation. Food preparator hands were recorded as the main factor contributing up to $39 \%$ of domestic food poisoning outbreaks (Ryan et $a l .$, 1996). The pathogen could be isolated also from $3(6.25 \%)$ of raw chicken, prepared and processed (precooked). Scott and Bloomfield (1990) identified the ability of the S. aureus to cause cross contamination for up to 24 hours via fingers' tips. It's important to mention that only one $(4.2 \%)$ of the workers aprons in the packing area 
(final product area) was contaminated by the pathogen, but none of the final products proved to harbor the pathogen. The researchers informed that it was an exceptional case as the worker doesn't belong to the final product area. Due to the over work he was accidentally called from the preparation area to support the other workers. It seems that the worker didn't follow the proper sanitary rules and thus represented a potential risk of cross contamination.

E. coli could be isolated from $2(3.6 \%)$ of the meat breaker and the cutting boards (preparation area) and from $3(6.25 \%)$ of raw prepared, processed and precooked meat and chicken. Gorman et al. (2002) reported that E. coli was isolated from 7 (28\%) chicken samples following their preparation, four of which were found to cross contaminate one or more of the premises surfaces such as counter top and draining boards.

Salmonella has been found to survive on dry surfaces for long periods of time (Humphrey et al., 1994). Salmonella failed to be detected in the examined raw food premises surfaces or final products. However, Gorman et al. (2002) reported that a small number of Salmonella infected chicken (8\%) had the ability to cause $100 \%$ cross contamination with other sites in the preparing premises including the counter top and the dishcloth.

It was obvious in the present study that all the final cooked products were negative for all the tested pathogens although the raw food materials and some of the processing facilities were contaminated. The result which indicate the proper and efficiency of the products heat treatment (time/ temperature). On the other hand, such a plant may need to decrease the intervals between cleaning and sanitization item to increase its ability to eradicate pathogens such as L. monocytogenes.

From this study, it was undoubtful that the contaminated raw food material is the real cause of disseminating microorganisms and contamination of various facilities (equipments and utensils) and workers' hands. Therefore, it is recommended to verify the quality of purchased raw material and to increase frequency of cleaning and disinfecting of the premises and the hygienic practice of the workers to decrease the risk of cross contamination.

\section{REFERENCES}


Aase, B.; Sundheim, G.; Langsrud, S. and Rorvik, L. (2000): Occurrence of and possible mechanism for resistance to quaternary ammonium compound in L. monocytogenes. Int. J. Food Microbiol. 62: 57-36.

Adesiyun, A.A. (1993): Prevalence of Listeria spp., Campylobacter spp., Salmonella spp., Yersenia spp. and toxigenic E. coli in meat and seafoods in Trinidad. Food Microbiol. 10: 395-403.

Anonymous (2001): Report of Nordic workshop on L. monocytogenes. Copenhagen, 26-27 September, the workshop financed by the Nordic committee of senior officials for food issues, project No. 68.10 .48 project leader savenquist, Denmark.

APHA (1992): Compendium of Methods for the Microbiological Examination of Foods. Vanderzant, C. and Splittstoesser, D. F. (eds.). $3^{\text {rd }}$ ed. Edwards Brothers, Washington, DC. USA.

Autio, T.; Hielm, S.; Mittinen, M.; Sjoberg, A. M.; Aarnisalo, K.; Bjorkroth, J.; Mattiasandholm, T. and Korkeala, H. (1999): Sources of L. monocytogenes contamination in a cold smoked rainbow trout processing plant detected by pulsed field gel electrophoresis typing. Appl. Environ. Microbiol. 65: 150-155.

Beresford, M.R.; Andrew, P.W. and Shama, G. (2001): L. monocytogenes attaches to many materials found in food processing environment. J. Appl. Bacteriol. 90: 1000-1005.

Bolton, D.J. Oser, A.H.; Cocoma, G.J.; Palumbo, S.A. and Miller, A.J. (1999): Integrating HACCP and TQM reduce pork carcass contamination. Food Technology 53 (4): 40-43.

Borch, E. and Arinder, P. (2002): Bacteriological safety issues in red meat and ready-to-eat meat products, as well as control measures. Meat Sci. 62, 281-390.

Chasseignaux, E.; Gerault, P. Toquin, M. T.; Salvat, G.; Colin, P. and Ermel, G. (2002): Ecology of L. monocytogenes in the environment of raw poultry meat and raw pork meat processing plants. FEMS Microbiology Letters, 210: 271-275.

Chasseignaux, E.; Toquin, M. T.; Ragimbeau, C.; Salvat, G.; Colin, P. and Ermel, G. (2001): Molecular epidemiology of $L$. monocytogenes isolates collected from the environment, raw meat and raw products in two poultry and pork processing plants. J. Appl. Microbiol. 91: 888-899. 
Faber, J.M. and Peterkin, P.I. (1991): Incidence and behavior of L. monocytogenes in meat products. In: In E. T. Ryser and E. H. Marth (ed.) Listeria, Listeriosis and Food Safety. P. 505-564. Marcel Dekker, New York.

FAO (1992): Manual of Food Quality Control. Part 4: Microbiological Analysis. FAO, Rome

Faustini, A.; Rossi, P.G. and Perucci, C.A.; (2003): Foodborne outbreak control teams. Outbreaks of foodborne diseases in the Lazio region, Italy: the results of the epidemiological field investigations. Eur. J. Epidemiol. 18: 699-702.

Gibbons, I.; Adesiyun, A.; Seepersadsingh, N. and Rahman, S. (2006): Investigation for possible source(s) of contamination of readyto-eat meat products with Listeria spp. and other pathogens in a meat processing plant in trindad. Food Microbiol. 23: 359-366.

Gillespie, I.; Little, C. and Michell, R. (2000): Microbial examination of cold ready-to-eat sliced meats from catering establishments in the United Kingdom. J. Appl. Microbiol. 88: 467-74.

Gorman, R.; Bloomfield, S. and Adley, C.C. (2002): A study of crosscontamination of foodborne pathogens in the domestic kitchen in the Republic of Ireland. Int. J. Microbiol. 76: 143-150.

Gudbjornsdottir, B.; Suihko, M.L.; Gustavsson, P.; Thorkelsson, G. Salo, S.; Sjoberg, A.M.; Niclassen, O. and Brdholt, S. (2004): The incidence of L. monocytogenes in meats, poultry and seafood plants in Nordic countries. Food Microbiol. 21, 217225.

Guerra, M.M.; Mclauchlin, J. and Bernardo, F.A. (2001): Listeria in ready-to-eat and unprocessed foods produced in Portugal. Food Microbiol. 18, 423-429.

Haeghebaet, S.; Sulem, P.; Deroudill, L. Vanneroy-Adenol, et al. (2003): Two outbreaks of Salmonella enteritidis phage type 8 linked to the consumption of Cantol cheese made with raw milk, France 2001. Eru. Surveill 8: 151-156.

Humphrey, T.J., Martin, K.W. and Whitehead, A. (1994): Contamination of hands and work surfaces with Salmonella enteritidis PT4 during the preparation of egg dishes. Epidemiology and Infection, 24 (261-264.

Lee, M.B. and Middleton, D. (2003): Enteric illness in Ontario Canada from 1997 to 2001. J. Food Prot. 66: 953-961. 
Lunden, J.M.; Autio, T.J. and Korkeala, H.J. (2002): Transfer of persistent L. monocytogenes contamination between food processing plants associated with a dicing machine. J. Food Prot. 65: 1129-1133.

Martinez-Tome, M. Vera, A.M. and Murcia, M.A. (2000): Improving the control of food production in catering establishments with particular reference to the safety of salads. Food Control, 11, 437-445.

Norrung, B. (2000): Microbiological criteria for L. monocytogenes in foods under special consideration of risk assessment approaches. Int. J. Food Microbiol. 62: 217-221.

Rosec, J.P.; Guiraud, J.P.; Dalet, C. and Richard, N. (1997): Enterotoxin production by staphylococci isolated from foods in France. Int. J. Food Microbiol. 35: 213-221.

Rouquete, C. and Berche, P. (1996): The pathogenesis of infection by $L$. monocytogenes. Microbiol. SEM 12, 245-258.

Ryan, M.J.; Wall, P.G.; Gilbert, R.J.; Griffin, M. and Rowe, B. (1996): Risk factors for outbreaks of infectious intestinal disease linked to domestic catering. Communicable Disease Report 6 (13), R 179-183.

Schuchat, A.B.; Swaminathan, and Broome, C.V. (1991): Epidemiology of human listeriosis. Clin. Microbiol. Res. 4: 169-183.

Scott, E. and Bloomfield, S.F. (1990): The survival and transfer of microbial contamination via cloths, hands and utensils. J. Appl. Bacteriol. 68: 271-278.

Slutsker, L. and Schuchat, A. (1999): Listeriosis in humans. P. 75-95. In E. T. Ryser and E. H. Marth (ed.) Listeria, Listeriosis and Food Safety. Marcel Dekker, New York.

Thevento, D.; Delignette-Muller, M.L.; Christieans, S. and Vernozy Rozand, C. (2005): Prevalence of L. monocytogenes in 13 dried sausage processing plants and their products. Int. J. Food Microbiol. 25; 102(1):85-94.

Tompkin, R.B.; Scott, V.N. Bernard, D.T.; Sveum, W.H. and Gambas, K.S. (1999): Guidelines to prevent post processing contamination from L. monocytogenes. Dairy Food Environ. Sanit. 19: 551-562. 
Tsuji, H.; Hamada, K.; Kawanishi, S.; Nakayama, A. and Nakajima, H. (2002): An outbreak of entrohemorrhagic E. coli O157 caused by ingestion of contaminated beef at grilled meat restaurant chain stores in the Kinki district in Japan: epidemiological analysis by pulsed filed gel electrophoresis. J. Pn. J. Infect. Dis. 55: 91-92.

USDA (2002): USDA provides update on Listeria recall. Release No. 0445.02. www.usda.gov. 